\title{
STUDENTS' PREFERENCES IN ONLINE ASSESSMENT PROCESS: INFLUENCES ON ACADEMIC PERFORMANCES
}

\author{
Unal CAKIROGLU \\ Department of Computer Education and Instructional Technology \\ Fatih Faculty of Education, Karadeniz Technical University \\ Trabzon, Turkey \\ Fatih ERDOGDU \\ Department of Computer Education and Instructional Technology \\ Fatih Faculty of Education, Karadeniz Technical University \\ Trabzon, Turkey \\ Mehmet KOKOC \\ Center for Research and Application in Distance Education \\ Karadeniz Technical University \\ Trabzon, Turkey \\ Melek ATABAY \\ Department of Computer Education and Instructional Technology \\ Fatih Faculty of Education, Karadeniz Technical University \\ Trabzon, Turkey
}

\section{ABSTRACT}

In the constructivist approach, various self-assessment techniques are being developed to enable students to assess themselves in the learning process. The purpose of the study is to investigate relation between students' preferences in assessment process and students' performances. The study was conducted with 67 sophomore students enrolled in Department of Computer Education and Instructional Technologies at a State University. The study was carried out in "Measurement and Evaluation in Education" course. At the beginning, Moodle LMS was used to define the preferences of students about their own assessment criteria (discussion, quiz, assignment and viewing of course content). Throughout the process, students were received the course instructional package in the classroom. Then they were asked to fill the assessment activities on the LMS. Students' actual performances in online activities in terms of their preference about assessment criteria was calculated as students course achievement scores. The mean value of the scores and the standard deviation were guided us to divide the participants into three groups (unsuccessful, moderately successful, successful) considering their means and standard deviations. Then, the preferences of students and their academic achievements were associated in each group. As a result, various criteria were come to front in both successful and unsuccessful groups. Surprisingly, none of the students preferred viewing course content and participating in discussions as the highest assessment criterion. Besides, it was found that all the students in successful group preferred viewing course content as lowest assessment criterion. The results indicated that, there were no prominent criteria in the relations between the preferences of students about assessment process and the academic performances. However, most of the students in unsuccessful group performed better in assignment although they did not preferred the assignment as the highest assessment criterion. At the end of the study, we noticed that while considering the criterion in the assessment process, taking students' perspectives and preferences into consideration motivated students positively and had somehow related to their academic achievements. Thus, it is hoped that the study can provides an insight to future studies to enrich assessment activities with giving responsibilities to students in learning, especially in assessment process.

Keywords: Students' preferences, assessment, online learning, moodle, academic achievement 


\section{INTRODUCTION}

The constructivist approach highlight students learning, tries to understand their individual improvements on the basis of their interests and habits, and aims to create an effective classroom environment, activities and methods (Richardson, 2003). Getting students to centre in learning process, students may construct meaningful knowledge based on their prior knowledge and experiences without strict classroom rules (Watson, 1996). Constructivist approach tends to use various teaching techniques and methods by getting students to centre in classroom. In evaluation stage, it declines the necessity of alternative evaluation methods to evaluate students' knowledge and abilities accurately (Ministry of National Education, 2006). Since, students construct their own knowledge it enables students to provide their own assessment and evaluation which is one of the indispensable component of the educational process (Kottail, 2009). In order to provide opportunities for students in the assessment process, teachers carry out various activities to direct the educational process according to students' demands. Therefore, students are able to do act new roles and have their own interpretations about learning. In relation to this, self-assessment provides individual routing for each student and decreases some of the burdens on teachers and eliminates the barriers between teachers and students (McConnell, 2006). As the students are decision makers about their own learning and assessment process, they feel the sense of responsibility and tend to act with this sense (McConnell, 2000).

Some research studies suggest that using different assessment methods within the framework of constructivist approach provide a positive contribution to their academic achievements and motivations and improve their thinking skills (Bahar, Nartgun, Durmus, \& Bicak, 2008; Duran, Mihladiz, \& Balliel, 2013; Duran, 2013). In this respect, different assessment methods are being developed for students to evaluate them in learning process. Moreover, it is thought that their active participation in decision-making stage in assessment criterion and evaluation process is an important component for their real life preparation (Cukusic, Garaca, \& Jadric, 2014). However, while implementing the selfassessment methods, students may assess themselves by putting forward certain criterion, students may act unilaterally and teachers cannot trust students much in some cases (Duran, Mihladiz, \& Balliel, 2003; Erdal, 2007; Silberman, 1996). In this case, the necessity of reducing teachers' concerns is revealed while giving responsibilities to students in the assessment process. It may be considered as sharing the assessment role of teacher in the learning process, but several studies addressed that students should act in the whole process of learning. Thus, to determine assessment criteria in a systematic way may contribute to the quality of the assessment process. Planning the assessment process through students' preferences may begin with defining the preferences, and continue with assessing the activities through these preferences. Because of the limitations in gathering students' preferences, many efforts have been provided to transfer this process in to online environment (Graff, 2003; Barrett, 2004). In this sense, the assessment activities generally have been conducted in multiple choice forms (Chang, Liang, \& Chen, 2013; Henly, 2003). Reviewing these forms makes teachers' tasks easier and so an objective evaluation can be available. This alternative assessment named as online self-assessment provide positive contribution to students' academic performances (Chang, Liang, \& Chen, 2013; Cukusic, Garaca, \& Jadric, 2014; Kaklauskas et al., 2010).

Conducted studies about online assessment have grown rapidly during the past decade (Zuckweiler, 2012). Despite the growing rapidly and several benefits about online assessment, empirical studies are still needed to explore the benefits of the online assessment methods (Spivey \& McMillan, 2014). For instance, in their study Russell et al. (2006) assert that an online learning environment enables to support learning, collaborative learning, and feedback between students and teachers. Also DeSouza and Fleming (2003) noticed that online assessment by supporting the learning process can be 
used in online learning environments. Moreover, online assessment can enhance learning, facilitate collaboration, and improve sense of community (Morgan \& O'Reilly, 2001).

Moreover, Buchanan (2001) emphasised that online assessment methods effect academic achievements positively even if students' face to face participation in courses are low. Furthermore, some research studies suggested giving roles to students in the assessment process by focusing on their motivation is getting higher (Birenbaum, 2007; Kaklauskas et al., 2010; Lai, \& Hwang, 2015). Birenbaum, (2007) pointed out that students' assessment preferences play a crucial role for understanding learning process. For example, Traub and McRury (1990) assert that students prefer multiple choices because these tests are easy to prepare and take and bring higher points. Thus they generally prefer to learn with studying for exams.

Online assessments are generally carried out through LMSs. Since, LMSs provide valuable affordances for assessing the students such as quizzes, discussions, navigation patterns, assignment, etc. Research studies generally addressed how to design and apply these activities on LMSs (Rapuano \& Zoino, 2006; Cavus, Uzunboylu \& Ibrahim, 2007). The effects of students' roles in the online assessment process may provide insights for instructors or instructional designers to construct efficient learning environments and to define the role of assessment in the learning process. Considering the potential of students' preferences in assessment, in this study; we purposed to investigate the relation between students' preferences about assessment criteria and their performances. Thus, the following research problem was guided to the study.

Within the scope of academic performances; to what extend did the students' assessment preferences take place during the learning process?

\section{METHODOLOGY}

\section{Participants}

This descriptive study involves sixty-seven $(n=67)$ sophomore voluntary university students at Computer Education and Instructional Technologies (CEIT) program from a state university in Turkey. We used convenience-sampling method to select the participants. The study was conducted in "Measurement and Evaluation in Education" course during 10 weeks. During the process, students applied some online activities using Moodle Learning Management System including quizzes, discussions, assignments, and viewing course contents. They have experiences on using Moodle components but they did not participate an online assessments process.

\section{Research Process}

In the research process, firstly participants were registered in Moodle LMS. Then, an online form was submitted to the participants to determine to what extend the online assessment activities (quizzes, discussions, assignments, and viewing course contents) effect on their course achievement in Moodle. Maximum rate was stated as $\mathbf{4 0 \%}$ for all activities. Students assigned their preferences as effect rates on course achievement totally100 points. Participants were informed that these points will be used as course achievement scores. They were also warned to be careful on assigning the meaningful rates including their real opinions by considering their qualifications and expectations in such activities. One student's preference about assessment criterion rates is illustrated below: 


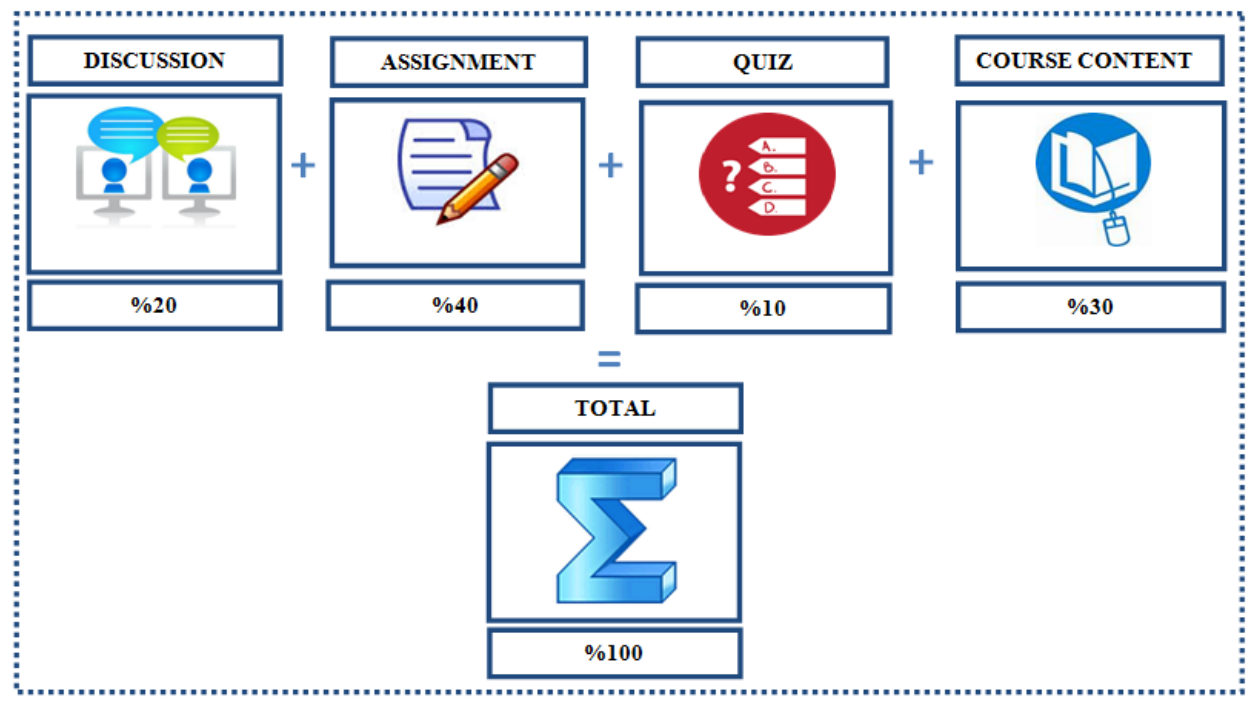

Figure 1. A sample for a student's preferences

As seen in Figure 1, the student preferred "assignment" activity as the highest assessment criterion (40\%) and "quiz" activity as lowest assessment criterion (\%10), totally 100 points. Furthermore, online activities uploaded in LMS for each week. In the study, students found opportunity for discussing on issues related to course content, participating in activities such as quizzes, assignments, viewing course content during 10 weeks. Each student's log data was stored automatically by Moodle for activities that they conducted.

Students' actual performances in online activities in terms of their preference about assessment criteria was calculated as students course achievement scores. The mean value of the scores and the standard deviation were guided us to divide the participants into three groups (unsuccessful, moderately successful, successful) considering their means and standard deviations. Then, a relation was investigated between students' preferences (SPr), students' performances (SPe) and their course achievement. While performing this, it was taken into consideration that they were active or not during the process. Active students can show high participation level in LMS and this was determined from students' log data and points about online activities. The points of online activities were calculated by norm-referenced evaluation. And also, viewing course content is important for determining that students are active or not.

The research process including the technical infrastructure, implementation, collecting data and data analysis phases that are shown in Figure 2: 


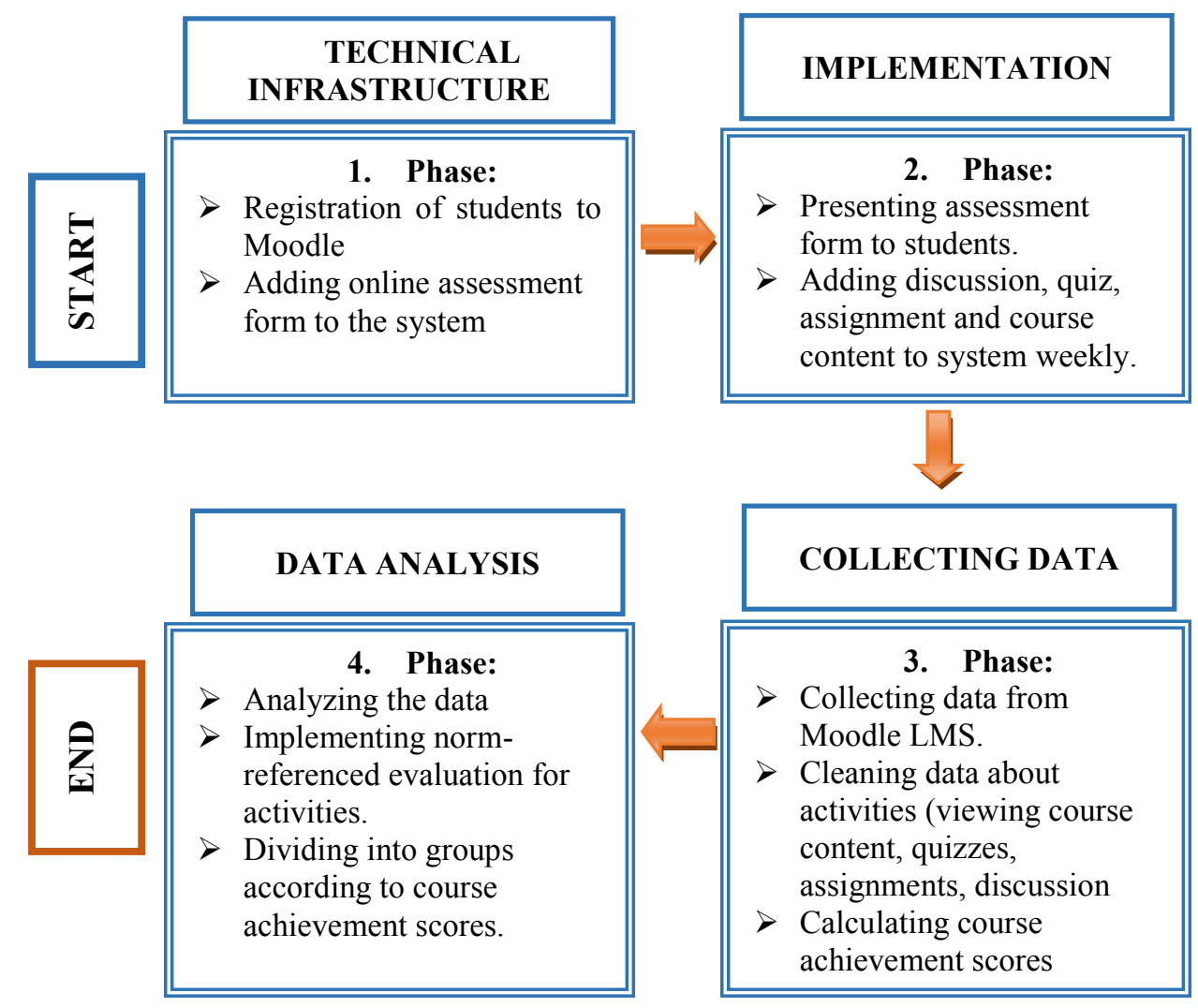

Figure 2. Research process

First step of this process was completed before the research started and implementation phase was carried out over $\mathbf{1 0}$ weeks. Collecting data phase continued during the study.

\section{Data Collection and Analysis}

In the data collection phase, data obtained from Moodle LMS were interpreted using descriptive analysis technique. Thanks to Moodle LMS which stores all students' log data about online activities, was the repository of data for each activity. Additionally, the scores from the activities calculated as course achievement scores at the end of the process which was from 0 to 100 . Students were grouped according to these scores in order to examine the preferences and performances in the successful, moderately successful and unsuccessful groups. It is determined that how many participants prefer quiz, assignment, viewing course content and discussion criterion to be assessed and how many participants show performances in the same direction of preferences. The findings were presented through students' preferences including their lowest and highest rated assessment criteria. Thus, to find out how many participants prefer which activities as the highest and lowest rated assessment criteria, norm-references evaluation method was conducted.

\section{RESULTS}

For understanding relation between $\mathrm{SPr}$ and $\mathrm{SPe}$, we classified students into groups aspect of course achievement scores. Participants' scores ranged from 21 to 93 points. The arithmetic mean of the achievement test was $69,76(\mathrm{SD}=12,79)$. The participants were classified in three groups by subtracting standard deviation from arithmetic mean or adding standard deviation to arithmetic mean: (1) unsuccessful group (under 56,96), (2) moderately successful group $(56,96$ to 82,55 ) and, (3) successful group (over 82,55). Scores of the participants included in unsuccessful, moderately successful, and successful groups ranged between 21 and 56, 58 and 79, 84 and 96 respectively. 
11 of 67 participants are in successful group, 50 of 67 are in moderately successful group and 6 of them are in unsuccessful group. In this study, we focused whether SPr and SPe differentiate in terms of success groups or not. The results of the study were as follows.

\section{Relationships between Groups and Assessment Criterion}

\section{Relation among SPr, SPe and, the preferred highest assessment criterion in groups}

In Figure 3, the numbers of students who chose online activities as assessment criterion for students affecting course achievement in highest rate is illustrated.

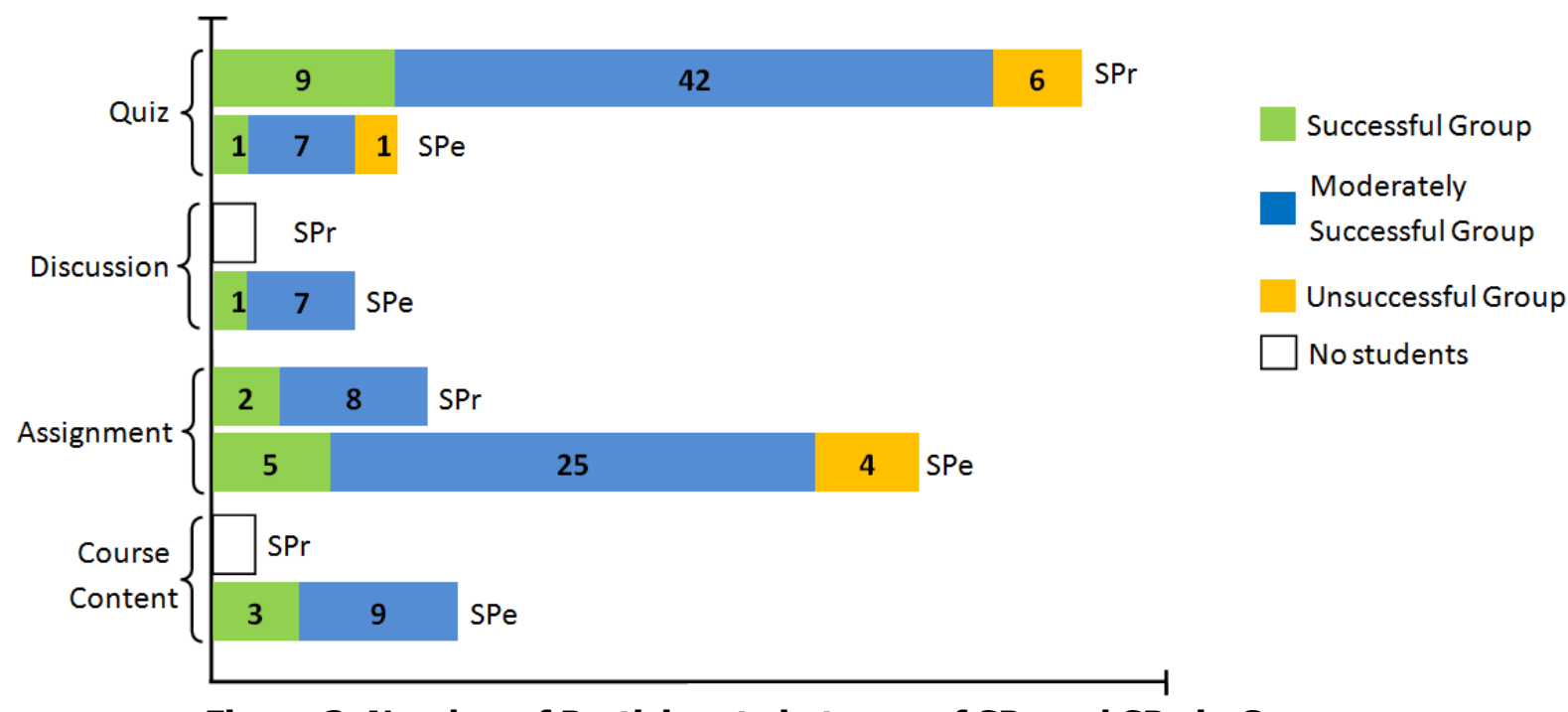

Figure 3. Number of Participants in terms of SPr and SPe in Groups

As shown in Figure 3, it is seen that none of the students preferred to be assessed as highest rate in online discussion and viewing course content. As the number of participants choosing quiz and assignments is 11 in successful group, this number is six in unsuccessful group. Although there are not any students preferring assignment in unsuccessful group, four students perform better in this direction. 42 of 50 moderately successful group members preferred quiz as the highest assessment criterion. Moreover, as indicated in Figure 3, as no participants preferred the viewing course content to be assessed as the highest assessment criterion, only 14 students performed better in this direction. When analysing students' log data in LMS, it was noticed that weekly mean duration of viewing course content is $\mathbf{5 8 , 9}$ minutes.

Overall, when viewing Figure 3 aspect of SPr and SPe, it emerges that only 19 students preferred the highest assessment criterion and show performance in the same direction as well. While 18 students show performance about preferences in moderately successful and successful group, only one student shows it in unsuccessful group.

\section{Relation among SPr, SPe and, the preferred lowest assessment criterion in groups}

The numbers of students who chose online activities as assessment criterion for students affecting course achievement in lowest rate is illustrated in Figure 4. When examining the Figure 4, it is seen that quiz and assignment activities were not preferred as the lowest assessment criterion by any of the students. All the students in successful group preferred the viewing course content as the lowest assessment criterion. There are only five of all students in successful group perform better about preferences in the viewing course content. $\mathbf{3 7}$ of $\mathbf{5 0}$ moderately successful group members stated that they preferred the course content activity as the lowest assessment criterion. 


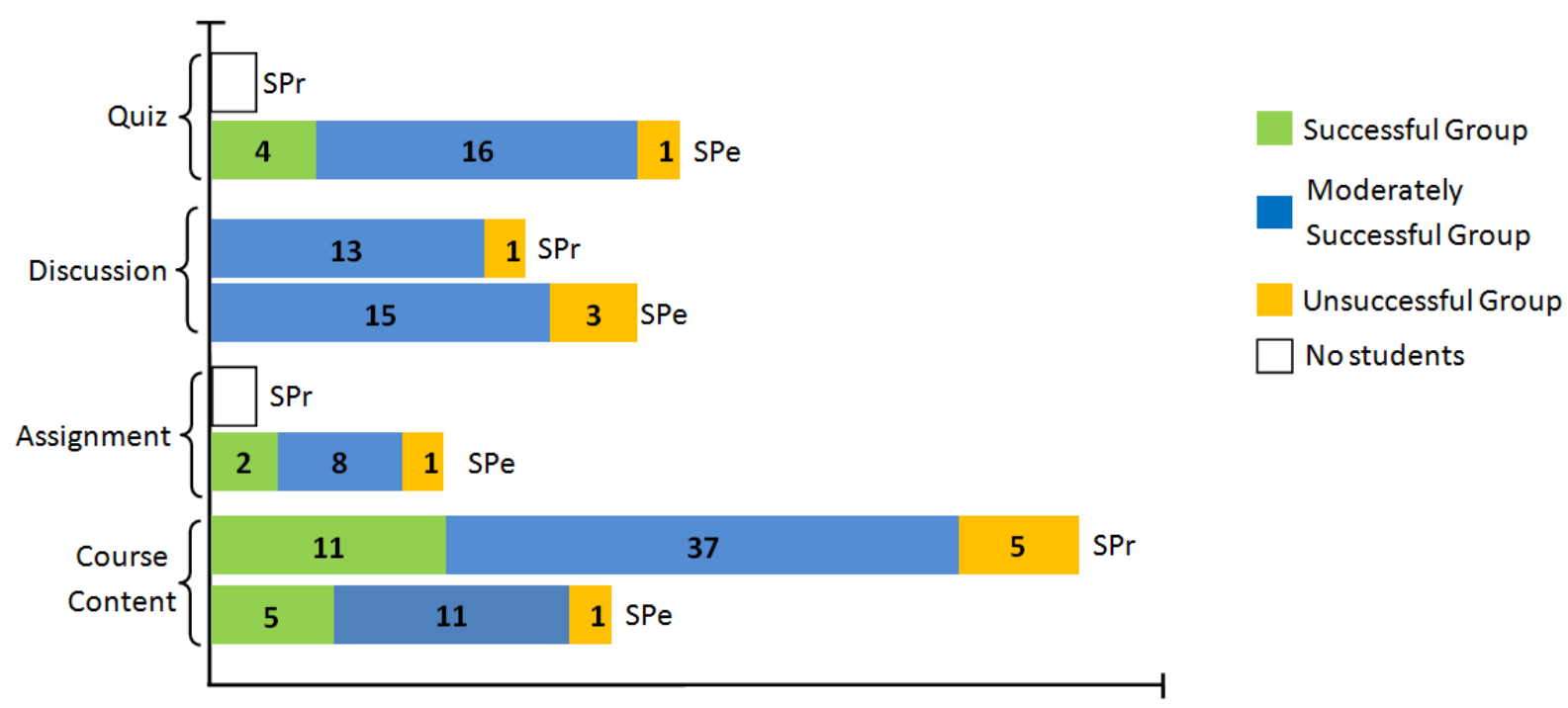

Figure 4. Number of Participants in terms of SPr and SPe in Groups

Overall, when analysing Figure 4 aspect of SPr and SPe, it emerges that only 31 students preferred the lowest assessment criterion and show performance in the same direction as well. While 29 students show performance about preferences in moderately successful and successful group, only two students show it in unsuccessful group.

\section{CONCLUSION AND DISCUSSION}

As a result, it was found that majority of the participants were in the successful group. As a SPr various criteria were come front in the groups. Assignment was mostly preferred as highest SPr in successful group, but no one preferred assignment criteria as the highest SPr in unsuccessful group. It is generally known that assessment has an important role in the learning processes and new teaching methods (Brown et al. 1994; Gibbs 1999; Scouller 1998).

The criteria using the course content and discussion were not preferred as the highest SPr by both successful and unsuccessful groups. Course content criterion is the lowest SPr by both successful and unsuccessful group. When students have the chance to decide on their own assessment process, they feel more responsibility and tend to act with the sense of this responsibility (McConnell, 2000). In addition, the criteria about use of course content were preferred with expecting the lowest score by all groups. It reflects that most of the students could not give up traditional assessment methods and their old habits about not spending much time within the context in the system. Similarly, Gijbels and Dochy (2006) pointed out that the perception of a too heavy workload can arguably be an explanation for decreased preference for assessment criteria and Gunnar (2008) addressed that students do not track the courses in the LMSs if they are not meaningful for them.

On the other hand, taking students' preferences in the assessment process is partially positively effected on students' academic achievements. Some other studies using online self-assessment techniques also found similar effects on students' achievements (Cukusic, Garaca, \& Jadric, 2014; Chang, Liang, \& Chen, 2013; Kaklauskas, 2010). Defining the assessment criteria through students' preferences bring out some unexpected achievement scores for students. For instance, students who preferred to be assessed with giving high rates to quiz, discussion and assignments, only students' who preferred assignments could get high grades in assignments. Surprisingly, some other students who did not expect higher scores from quizzes and assignments also got their highest scores from these activities. In addition, it was observed that quiz and the assignment were the most preferred activities for highest SPr. Since they were accustomed to be assessed through quizzes, exams or assignments in their educational 
life, the result can be thought as a reflection from their previous experiences. However, it was found that students could not get the highest grade from their highest grade criterion that they preferred. Most of the students got the highest grade from assignment criterion although they preferred the quiz criterion as the highest rate. This is possibly because of their conventional assessment habits. In this sense, Struyven Dochy and Janssens (2006), argues that the way in which a student perceives about learning and studying, follow the way in which he tackles assignments and assessment tasks.

Since constructivist learning approach suggest students acting in the assessment in the instructional process, it is not easy to control students' assessment behaviours. Giving responsibility may support students' meaningful learning, but students sometimes cannot know the activities that they are better. This is may be due to their study habits or their experiences which they brought from their conventional courses. The study provided some clues that it is difficult for students to give up their habits from behaviour approach. Using online environment for assessment process is also useful to give responsibilities to the students. In addition, LMSs provide affordances for instructor to organize the assessment process using online environments.

Consequently, it is concluded that as the criteria for taking students' perspectives into account and their own preferences have a motivating role on students due to the idea of determining their own assessment process. The main difficulty for students is to estimate their real abilities. In this sense, instructors by reflecting their experiences may help students in the assessment process. Another conclusion may be drawn from the study is, there is no directly relation occurred between students' preferences and academic performances. Future studies may be focused on some qualitative data to interpret the reasons for why majority of students prefer classical assessment techniques.

\title{
BIODATA and CONTACT ADDRESSES of AUTHORS
}

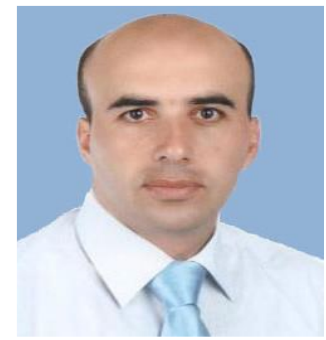

Unal CAKIROGLU is currently an associate professor at the Department of Computer Education and Instructional Technologies at Karadeniz Technical University. His academical qualifications were in Computer Engineering (B. Sc.), in Computer Engineering (M.S) and Technology of Education (PhD.). He teaches computer programming, operation systems, and other IT related courses. His research interests include e-learning applications, social networking in education, technology integration and distance education.

\author{
Unal CAKIROGLU \\ Department of Computer Education and Instructional Technology \\ Fatih Faculty of Education, Karadeniz Technical University \\ 61300, Trabzon, TURKEY \\ Phone: +90 4623777113 \\ E-mail: cakiroglu@ktu.edu.tr
}

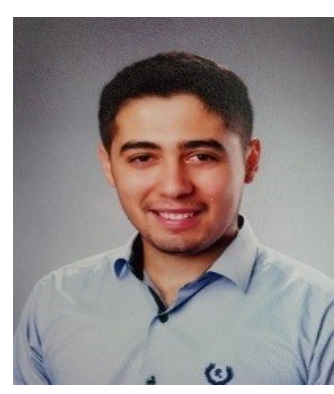

Fatih ERDOGDU is a research assistant of Computer Education and Instructional Technology at Faculty of Education, Karadeniz Technical University. Also, he is PhD at the same department. He graduated from Middle East University, Faculty of Education, Department of Computer Education and Instructional Technology in 2011. He graduated from Computer Education and Instructional Technology at Gazi University with the degree of master in 2015. His academic interest areas are open and distance learning, education futures, e-learning and humorous learning in online learning environments. 


\section{Fatih ERDOGDU}

Department of Computer Education and Instructional Technology

Fatih Faculty of Education, Karadeniz Technical University

61300, Trabzon, TURKEY

Phone: +90 4623776860

E-mail: ferdogdu@ktu.edu.tr

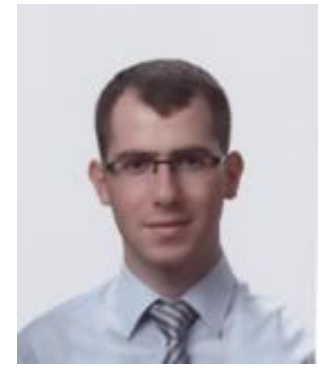

Mehmet KOKOC is currently a PhD researcher at Center for Research and Application in Distance Education, Karadeniz Technical University. He graduated from Ege University, Faculty of Education, Department of Computer Education and Instructional Technology at June, 2009. Dr. Kokoç gained his Ph.D. in Computer Education and Instructional Technology, Hacettepe University at December, 2015. His academic interest areas are learning analytics, educational data mining, open and distance learning, social media in education and professional development of teachers.

\section{Mehmet KOKOC}

Center for Research and Application in Distance Education

Karadeniz Technical University, 61300, Trabzon, TURKEY

Phone: +90 4623776860

E-mail: mkokoc@ktu.edu.tr

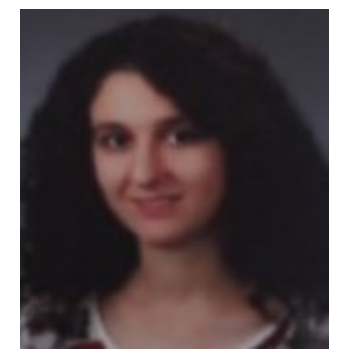

Melek ATABAY is a Research Assistant of Department of Computer Education and Instructional Technology Fatih Faculty, Karadeniz Technical University. She graduated from Ankara University, Faculty of Education, Department of Computer Education and Instructional Technology at June, 2009. She is a master student in this department on Educational Technology from February, 2015. Her academic interest areas are e-learning environments, study habits in online learning, gamification, social network analysis, open and distance learning.

\section{Melek ATABAY}

Department of Computer Education and Instructional Technology

Fatih Faculty of Education, Karadeniz Technical University

61300, Trabzon, TURKEY

Phone: +90 4623776761

E-mail: melekatabay@ktu.edu.tr

\section{REFERENCES}

Aydogdu, M., \& Kesercioglu, T. (2005). Ilkogretimde fen ve teknoloji ogretimi [Teaching Science and Technology in Primary School]. Ankara: Ani Publishing.

Bahar, M., Nartgun, Z., Durmus, S., \& Bicak, B. (2008). Geleneksel-alternatif olcme ve degerlendirme ogretmen el kitabi [Teacher Handbook of Traditional-Alternative Measurement and Evaluation]. Ankara: Pegem Academy Publishing.

Barrett, H. (2004). Differentiating electronic portfolios and online assessment management systems. Presented in Society for Information Technology \& Teacher Education International Conference (Vol. 2004, No. 1, pp. 46-50).

Birenbaum, M. (2007). Assessment and instruction preferences and their relationship with test anxiety and learning strategies. Higher Education, 53(6), 749-768. 
Brown, S., Rust, C., \& Gibbs, G. (1994). Strategies for diversifying assessment in higher education. Oxford: The Oxford Centre for Staff and Learning Development, Oxford Brookes University

Buchanan, T. (2001). The efficacy of a world-wide web mediated formative assessment. Journal of Computer Assisted Learning, 16(3), 193-200. http://dx.doi.org/10.1046/j.1365- 2729.2000.00132.x.

Cavus, N., Uzunboylu, H., \& Ibrahim, D. (2007). Assessing the success rate of students using a learning management system together with a collaborative tool in web-based teaching of programming languages. Journal of educational computing research, 36(3), 301-321.

Chang, C. C., Liang, C., \& Chen, Y. H. (2013). Is learner self-assessment reliable and valid in a Web-based portfolio environment for high school students? Computers \& Education, 60(1), 325-334.

Cukusic, M., Garaca, Z., \& Jadric, M. (2014). Online self-assessment and students' success in higher education institutions. Computers \& Education, 72, 100-109.

DeSouza, E., \& Fleming, M. (2003). A comparison of in-class and online quizzes on student performance. Journal of Computing in Higher Education, 14, 121-134.

Dochy, F., \& McDowell, L. (1997). Assessment as a tool for learning. Studies in Educational Evaluation, 23(4), 279-298.

Duran, M., Mihladiz, G., \& Balliel, B. (2013). The competency level of elementary school teachers' towards the alternative assessment methods. Mehmet Akif Ersoy Universitesi Egitim Bilim/eri Enstitusu Dergisi, 2(2), 26-37.

Erdal, H. (2007). The investigation of measurement \& evaluation parts in the new elementary school mathematics curriculum (case of Afyonkarahisar). Unpublished Master Thesis, Afyon Kocatepe University, Graduate School of Social Science, Afyon, Turkey.

Gibbs, G. (1999). Using assessment strategically to change the way students learn. In S. Brown \& A. Glasner (Eds.), Assessment matters in higher education: Choosing and using diverse approaches (pp. 41-53). Buckingham: SRHE and Open University Press.

Gijbels, D., \& Dochy, F. (2006). Students' assessment preferences and approaches to learning: can formative assessment make a difference? Educational studies, 32(4), 399-409.

Graff, M. (2003). Cognitive style and attitudes towards using online learning and assessment methods. Electronic Journal of e-learning, 1(1), 21-28.

Gulnar, B. (2008). Bilgisayar ve internet destekli uzaktan egitim programlarinin tasarim, gelistirme ve degerlendirme asamalari (SUZEP Ornegi) [Phases of design, development and evaluation in computer and internet assisted distance learning programs (Case of SUZEP)]. Selcuk Universitesi Sosyal Bilim/er Enstitusu Dergisi, (19), 259-271.

Henly, D. C. (2003). Use of web-based formative assessment to support student learning in a metabolism/nutrition unit. European Journal of Dental Education, 7(3), 116-122

Kaklauskas, A., Zavadskas, E. K., Pruskus, V., Vlasenko, A., Seniut, M., Kaklauskas, G. \& Gribniak, V. (2010). Biometric and intelligent self-assessment of student progress system. Computers \& Education, 55(2), 821-833.

Kottail, N. K. (2009). Meaning making and self-evaluation. Online Submission. Retrieved from http://files.eric.ed.gov/fulltext/ED504124.pdf 
Lai, C. L., \& Hwang, G. J. (2015). An interactive peer-assessment criterion development approach to improving students' art design performance using handheld devices. Computers \& Education, 85, 149-159.

McConnell, D. (2006). E-learning groups and communities: Imagining learning in the age of the internet. OU Press.

McConnell, D. (2000). Implementing computer supported cooperative learning. London: Kogan Page.

Morgan, C., \& O'Reilly, M. (2001). Innovations in online assessment. Lockwood, F. E Gooley, A.. Innovation in Open \& Distance Learning: Successful Development of Online and WebBased Learning. London: Kogan Page, 179-188.

Ministry of National Education, (2006). Teaching Curriculum of Science and Technology for Primary Schools. Retrieved from

http: //ttkb.meb.gov.tr/program2.aspx?islem $=28 k n o=25$

Spivey, M. F., \& McMillan, J. J. (2014). Classroom versus Online Assessment. Journal of Education for Business, 89(8), 450-456.

Struyven, K., Dochy, F., Janssens, S., \& Gielen, S. (2006). On the dynamics of students' approaches to learning: The effects of the teaching/learning environment. Learning and Instruction, 16(4), 279-294.

Rapuano, S., \& Zoino, F. (2006). A learning management system including laboratory experiments on measurement instrumentation. Instrumentation and Measurement, IEEE Transactions on, 55(5), 1757-1766.

Richardson, V. (2003). Constructivist Pedagogy. Teacher College Record 105(9): 1623-1640.

Russell,]., Elton, L., Swinglehurst, D., \& Greenhalgh, T. (2006). Using the online environment assessment for learning: A case study of a web-based course in primary care. Assessment \& Evaluation in Higher Education, 31(4), 465--478.

Scouller, K. (1998). 'The influence of assessment method on students' learning approaches: Multiple choice question examination versus assignment essay. Higher Education, 35, 453-472.

Silberman, M.-L. (1996). Active Learning 101 Strategies to Teach Any Subject. Boston: Allyn \&Bacon. 6-7.

Traub, R. E., \& MacRury, K. (1990). Multiple choice vs. free response in the testing of scholastic achievement. In K. Ingenkamp \& R. S. Jager (Eds.), Tests und Trends 8: Jahrbuch der Pa"dagogischen Diagnostik (pp. 128-159). Weinheim und Basel: Beltz.

Watson, B. (1996). Instructional Planning and Contemporary Theories of Learning: Is This a Self-contradiction?. In Proceedings of European Conference on Artificial Intelligence in Education, ed. P. Brna, A. Paiva, and J. Self, 23-30. Lisbon: Colibri.

Zuckweiler, K. M. (2012). Using technologies to enhance student learning in the online classroom. Decision Line: Decision Sciences Institute, 43, 6-8. 